\title{
УAK 657.01:330.34
}

\section{О. В. Харламова,}

А. е. н., Аоцент, професор кафедри фінансово-економічної безпеки, обліку і аудиту, Харківський національний університет міського господарства імені О. М. Бекетова, ORCID ID: 0000-0002-9422-4990

T. K. Метіль,

к. е. н., доцент, завідувач кафедри управління підприємницькою та туристичною Аіяльністю, Ізмаїльський Аержавний гуманітарний університет

ORCID ID: 0000-0002-4553-4343

T. М. Уманець, викладач кафеАри управління підприємницькою та туристичною Аіяльністю, Ізмаїльський Аержавний гуманітарний університет

ORCID ID: 0000-0002-8517-9761

K. М. ОГАаНСЬКИй, к. е. н., Аоцент, Аоцент кафеАри економіки та соціально-трудових відносин, Університет митної справи та фінансів

ORCID ID: 0000-0002-8126-4977

DOI: $10.32702 / 2306-6792.2022 .2 .31$

\section{ПРАКТИЧНІ АСПЕКТИ ЗАПРОВААЖЕННЯ УПРАВАІНСЬКОГО ОБАІКУ НА ПІАПРИЕМСТВАХ IНАУСТРIї ГОСТИННОСТI}

\author{
O. Kharlamova, \\ Doctor of Economic Sciences, Associate Professor, Professor of the Department of Financial and Economic \\ Security, Accounting and Auditing, O. M. Beketov National University of Urban Economy in Kharkiv \\ T. Metil, \\ $\mathrm{PhD}$ in Economics, Associate Professor, Head of the Department of Business and Tourism Management, \\ Izmail State Humanities University \\ T. Umanets, \\ Lecturer of the Department of Business and Tourism Management, Izmail State Humanities University \\ K. Ohdanskyi, \\ $\mathrm{PhD}$ in Economics, Associate Professor, Associate Professor of the Department of Economics \\ and Social and Labor Relations, University of Customs and Finance
}

\section{PRACTICAL ASPECTS OF THE INTRODUCTION OF MANAGEMENT ACCOUNTING AT THE ENTERPRISES OF THE HOSPITALITY INDUSTRY}

У статті визначаються особливості запровадження та вплив системи управлінського обліку на результативність підприємств індустрії гостинності. Обрано 30 компаній м. Києва та Київської області на основі стратифікованого методу 3 метою отримання адекватної вибірки на основі економічного критерію. Було розроблено анкету, що має три розділи. Використано кількісний піАхіА Аля аналізу впливу системи управлінського обліку з метою оцінки проАуктивності компаній-користувачів та компаній-некористувачів. Аля аналізу впливу систем практик управлінського обліку на результативність компаній використано непараметричний підхід. Результати висвітлили позитивні та статистично значущі зв'язки між більшістю інструментів управлінського обліку та показниками готельного бізнесу. Аоведено, що компанії, які вже використовують методи управлінського обліку, виявляють великий інтерес до нових інструментів стратегічного управлінського обліку. Обгрунтовано на основі U-критерію Манна-Уітні, що система обліку витрат та стратегічний управлінський облік мають позитивне вплив на фінансові та нефінансові показники Аіяльності компаній індустрії гостинності. 
The article defines the features of the introduction and the impact of the management accounting system on the effectiveness of hospitality industry enterprises. 30 companies of Kiev and Kiev region were selected on the basis of a stratified method in order to obtain an adequate sample based on an economic criterion. A questionnaire has been developed, which has three sections. A quantitative approach was used to analyze the impact of the management accounting system in order to assess the productivity of user companies and non-supplier companies. To analyze the impact of management accounting practice systems (cost accounting, budgeting, decision support systems, efficiency assessment) on the effectiveness of companies, a nonparametric approach was used. The results highlighted positive and statistically significant links between most management accounting tools and hotel business indicators. The results of the Spearman Ranking correlation coefficient test show positive and statistically significant links between most management accounting tools and hotel business indicators. In particular, cost accounting systems and strategic Management accounting have a positive and significant ratio relative to the indicators of financial and non-financial activities. In contrast, budgeting and performance evaluation methods have a positive and significant impact only on the return on investment. Decision support systems do not affect the results of the company's activities. It is proved that companies that already use management accounting methods show great interest in new tools of strategic management accounting. Companies that are just starting to implement management accounting are showing interest in more traditional management accounting tools - cost accounting and budgeting systems. It is justified on the basis of the Mann-Whitney $\mathrm{U}$-criterion that the cost accounting system and strategic management accounting have a positive impact on the financial and non-financial performance indicators of the hospitality industry companies. The results of the study can be useful for raising awareness of entrepreneurs about the advantages (in the context of competitiveness and efficiency from the introduction of management accounting methods.

Ключові слова: управлінсъкий облік, бюджетування, стратегічний управлінський облік, система обліку витрат, ефективність.

Keywords: management accounting, budgeting, strategic management accounting, cost accounting system, efficiency.

\section{ПОСТАНОВКА ПРОБЛЕМИ}

У контексті обраного дослідження проблеми бухгалтерського обліку для цілей управління потребують глибокого аналізу сутності та призначення управлінського обліку в сучасній економіці, внутрішньому контролі та бюджетуванні.

На нашу думку, управлінський облік має забезпечити умови для об'єктивного аналізу ефективності діяльності підприємства, а також забезпечити врахування побажань всіх зацікавлених сторін управлінських рішень. Крім того, своєчасне подання інформації про витрати та отримані доходи підприємства та його дочірніми підприємствами відповідно до вимог облікової політики, бюджетування фінансово-господарської діяльності, дозволяє аналізувати інвестиційні проєкти, здійснювати внутрішній контроль, застосовувати сучасні методи обліку витрат, розраховувати кошториси продукції, формувати трансфертні рейтинги.

Індустрія гостинності як третинний сектор економіки розвивається швидкими темпами в інформаційній економіки. Це потребує запровадження ефективного управлінського обліку з метою отримання об'єктивної та релевантної інформації для прийняття управлінських рішень щодо досягнення місії підприємства.

\section{АНАЛІЗ ОСТАННІХ ДОСЛІДЖЕНЬ І ПУБЛІКАЦІЙ}

Серед сучасних досліджень управлінського обліку необхідно відокремити, насамперед, такі.

Костякова А.А. визначає, що сучасний бухгалтерський облік повинен орієнтуватися не стільки на зовнішніх користувачів інформації, скільки на задоволення потреб апарату управління підприємства [1]. 3 цією метою виникає потреба посилити інформаційні функції обліку, організувати аналітичний облік, виходячи 3 потреб управління витратами [1].

Бруханський Р.Ф. підкреслює вимоги сучасного менеджменту - передбачають диференціацію підходів до управління підприємством у розрізі тактичних і стратегічних векторів [2]. Теоретичне обгрунтування функцій стратегічного управлінського обліку як системи інформаційної підтримки прийняття стратегічних управлінських рішень формує передумови уточнення 110 призначення і генерування спектру методологічного інструментарію для виконання поставлених перед нею цілей у системі стратегічного менеджменту [2].

Аерій В.А. та Гуменна-Аерій М.В. стверджують, що управлінський облік і аналіз бізнеспроцесів в українських підприємствах виробничої сфери здійснюється на задовільному рівні [3]. Автори запропонували створити На- 
Таблиця 1. Загальна інформація про компанії індустрії гостинності (Фрагмент)

\begin{tabular}{|l|l|}
\hline \multicolumn{1}{|c|}{ Інформація } & \multicolumn{1}{c|}{$\%$} \\
\hline 1. Власники: & $\mathrm{X}$ \\
\hline 1 & 10,5 \\
\hline 2 & 41,6 \\
\hline $3-5$ & 44,7 \\
\hline 6 та більше & 3,2 \\
\hline Кількість працівників & $\mathrm{X}$ \\
\hline $1-19$ & 24,6 \\
\hline $20-49$ & 39,3 \\
\hline $50-99$ & 29,9 \\
\hline більше 100 & 6,2 \\
\hline $\begin{array}{l}\text { Середній грошовий обіг } \\
\text { (грн) }\end{array}$ & $\mathrm{X}$ \\
\hline$>1$ млн & 24,2 \\
\hline$>1<2$ млн & 31,1 \\
\hline$\geq 2<10$ млн & 38,5 \\
\hline$>10$ млн & 6,2 \\
\hline
\end{tabular}

Ажерело: авторське дослідження.

уково-дослідний інститут фінансового і управлінського обліку, контролю та аналізу [3].

Турова $\Lambda . \Lambda$. та Костюнік О.В. зазначають, що невирішені питання практичного впровадження і функціонування систем управлінського обліку викликають неефективне (і нераціональне) використання фінансових інтелектуальних, організаційних, інформаційних ресурсів підприємств, неадекватні витрати на уніфікацію бізнес(процесів, на автоматизацію управління (придбання засобів обчислювальної техніки та програмного забезпечення) [4].

Афанас'єва I.I. та Розмислов О.М. проаналізували основні групи інструментарію стратегічного управлінського обліку, комплексне використання яких дозволяє виконувати завдання будь-якої складності та забезпечити інформацією усі напрями управління. завдань облікової інформації екологічно-соціального характеру та наслідки прийняття управлінських рішень [5].

Мазіна O.I. у статті [6] доводить, що дотримання глобальних принципів управлінського

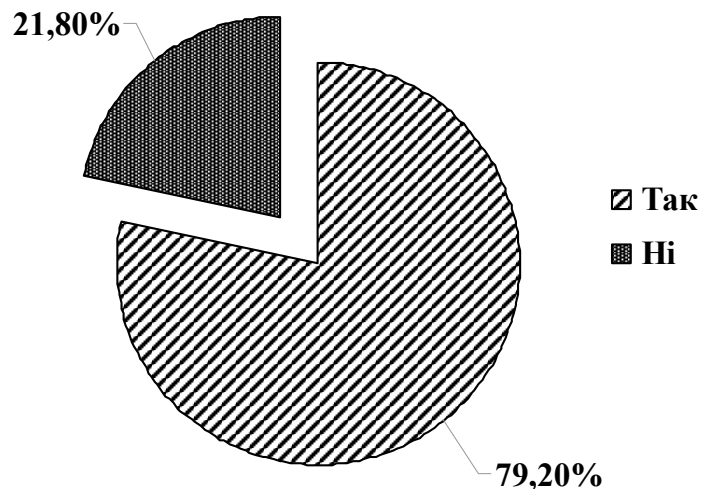

Рис. 1. Практика запровадження управлінського обліку

Ажерело: авторське дослідження. обліку дозволяє досягти зростання вартості бізнесу та забезпечити сталий розвиток економіки; важливе значення мають компетенції фахівців, які приймають управлінські рішення [6].

Відповідно до проведеного контент-аналізу, можна зробити висновок, що українські вчені у дослідженнях, зазвичай, розглядають питання теоретичного обгрунтування необхідності запровадження управлінського обліку на підприємствах. Потребує розширення наукових праць стосовно саме практичних аспектів запровадження управлінського обліку (тактичного та стратегічного) на вітчизняних підприємствах, а саме: вивчення досвіду запровадження управлінського обліку з метою визначення недоліків та подальших заходів удосконалення цього виду обліку як обліково-аналітичного забезпечення прийняття управлінських рішень.

\section{META CTATTI}

Метою статті є дослідження практичних аспектів запровадження управлінського обліку на підприємствах індустрії гостинності.

\section{ВИКЛАД ОСНОВНОГО МАТЕРІАЛУ ДОСЛІДЖЕННЯ}

3 метою визначення досвіду запровадження управлінського обліку на підприємствах індустрії гостинності було обрано готелі м. Києва та Київської області. Було обрано цей географічний район як найбільш значущий в Україні - з економічної та конкурентної точки зору (туристична присутність, міжнародні інвестиції та зайнятість).

Аля визначення компаній, які підлягають аналізу, було використано стратифіковану методологію випадкової вибірки на основі економічного критерію.

Такий підхід дозволяє включити до вибірки декілька компаній з різними характеристиками (за обігом, розміром та кількістю працівників). Крім того, ця методологія гарантує кращу репрезентативність вибірки, що покращують ефективність оцінок.

Усі дані були зібрані за допомогою анкети, яка підготовлена за участю консультантів, галузевих експертів, адміністративних та фінансових менеджерів готельних компаній. На першому етапі дослідження було проведено пілотний тест, щоб оцінити ефективність запитань та запобігти можливому викривленню даних.

Анкета була поділена на дві частини. Перший розділ містить загальну інформацію про компанію: рік заснування, керівництво, рівень освіти працівників та результативність. У таб- 


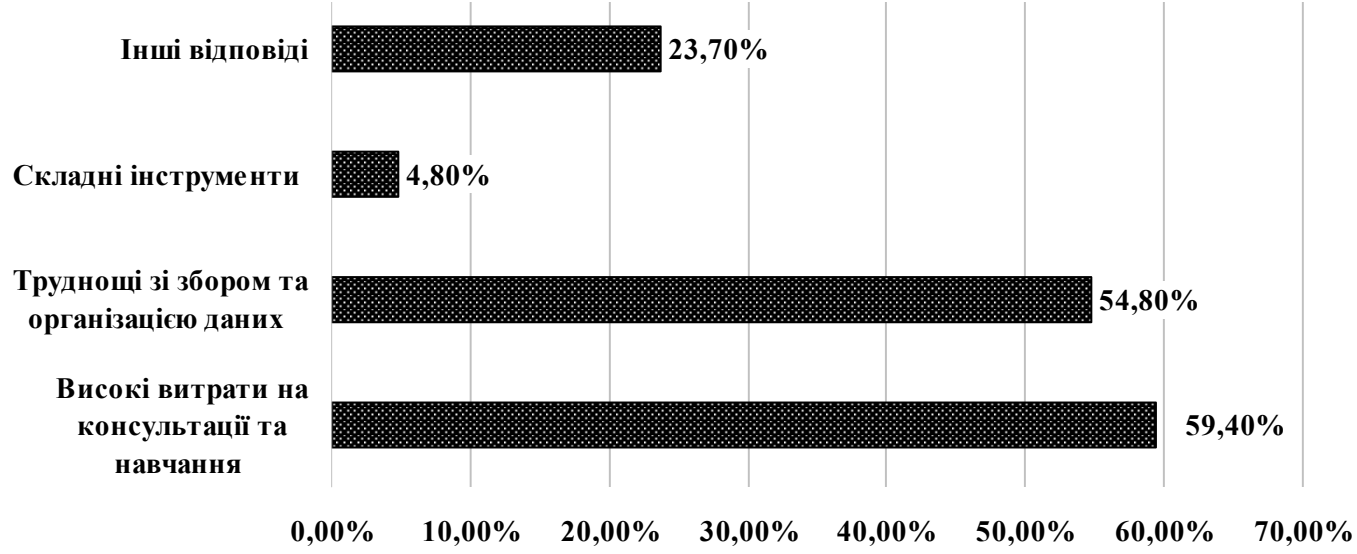

Рис. 2. Мотиви не запровадження практики управлінського обліку

Ажерело: авторське дослідження.

лиці 1 наведено основні характеристики проаналізованих компаній, які отримані в результаті обробки розділу 1 анкети.

Аругий розділ анкети включає запитання стосовно застосування інструментів управлінського обліку (формальні та неформальні), а також мотивація підприємця та/або менеджера до цих інструментів. Останній розділ містить деякі контрольні запитання з метою перевірки узгодженості відповідей. Анкета супроводжується глосарієм, який ілюструє основні характеристики аналізованих інструментів управлінського обліку. 3 компаніями зв'язалися спочатку електронною поштою, а потім по телефону, пояснивши мету аналізу та забезпечивши конфіденційність отриманої інформації.

Загалом, 30 компаній заповнили анкету протягом терміну, встановленого для завершення етапу збору даних. На рисунку 1 показано кількість компаній, які використовують принаймні один інструмент управлінського обліку.

У зв'язку з цим можна зазначити, що багато компаній, які не використовують практику управлінського обліку (ПУО), що використовують різні інструменти (менш формалізовані) для вимірювання фінансових та нефінансових результатів компанії.

На рисунку 2 наведено основні причини не запровадження цих інструментів. Насамперед це висока вартість впровадження та труднощі, що пов'язані зі збором та організацією даних.

Було виконано $\chi^{2}$ - тест на упередження щодо відсутності даних - чи дали перші 20 й останні 20 респондентів суттєво різні відповіді. Тести не виявили істотних відмінностей.

Аля підвищення достовірності результатів використано структуровану анкету, переважно із запитаннями закритого типу. Цей підхід має перевагу, що полегшує збір даних з метою покращення якості аналізу результатів. Аекілька
Таблиця 2. Практика управлінського обліку

\begin{tabular}{|l|l|l|}
\hline \multicolumn{1}{|c|}{ Інструменти } & \multicolumn{1}{c|}{$\begin{array}{c}\text { Середнє } \\
\text { значення }\end{array}$} & $\begin{array}{c}\text { Зважена } \\
\text { дисперсія }\end{array}$ \\
\hline Системи обліку витрат & 5,21 & 0,92 \\
\hline Бюджетування & 4,12 & 0,88 \\
\hline Оцінка ефективності & 3,81 & 1,15 \\
\hline $\begin{array}{l}\text { Системи підтримки } \\
\text { прийняття рішень }\end{array}$ & 2,45 & 2,45 \\
\hline $\begin{array}{l}\text { Стратегічний } \\
\text { управлінський облік }\end{array}$ & 1,65 & 2,16 \\
\hline
\end{tabular}

Ажерело: авторське дослідження.

питань, що стосуються систем управлінського обліку, надали можливість отримати відповіді за 5-бальною шкалою типу Аайкерта: від 1 (низька важливість) до 5 (максимальна важливість).

Відповідно до попередніх досліджень [79], щоб оцінити використання та важливість практики управлінського обліку в готельних компаніях, було взято до уваги 56 методів, які були відокремлено у 5 основних категорій:

1) облік витрат (абсорбційна калькуляція, змінна калькуляція, АВС, стандартна калькуляція тощо);

2) бюджетування (тип бюджету, планування, АВВ тощо);

3) системи підтримки прийняття рішень (Profitability Measures, BSC, Benchmarking тощо);

4) оцінка ефективності (аналіз прибутковості клієнтів, CVP- аналіз тощо);

5) стратегічний управлінський облік (аналіз конкурентів, аналіз загроз і можливостей, ABM тощо).

Аля оцінки фінансових показників було використано ROI (Return on Investments) [10; 11]. Аля оцінки нефінансових показників було використано деякі специфічні галузеві показники, такі як: задоволеність клієнтів, оцінка послуг та персоналу тощо.

У таблиці 2 показано використання ПУО (більшість компаній використовують системи управлінського обліку та бюджетування). 
Таблиця 3. Практика управлінського обліку та ефективність

\begin{tabular}{|c|c|c|c|c|c|c|c|}
\hline Інструменти & 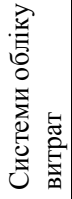 & 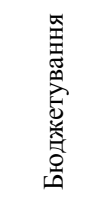 & 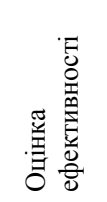 & 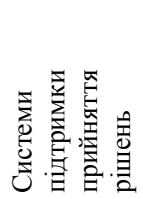 & 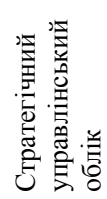 & 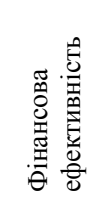 & 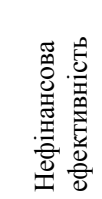 \\
\hline Системи обліку витрат & - & $\begin{array}{l}0,606^{* *} \\
0,000\end{array}$ & $\begin{array}{l}0,548^{* *} \\
0,000\end{array}$ & $\begin{array}{l}0,421 * * \\
0,000 \\
\end{array}$ & $\begin{array}{l}0,435 * * \\
0,000\end{array}$ & $\begin{array}{l}0,117 * \\
0,010\end{array}$ & $\begin{array}{l}0,123^{*} \\
0.029\end{array}$ \\
\hline Бюджетування & & - & $\begin{array}{l}0,521 * * \\
0,000\end{array}$ & $\begin{array}{l}0,601^{* *} \\
0,001\end{array}$ & $\begin{array}{l}0,665^{* *} \\
0,000\end{array}$ & $\begin{array}{l}0,275^{* *} \\
0,001\end{array}$ & $\begin{array}{l}0,121 \\
0,121\end{array}$ \\
\hline Оцінка ефективності & & & 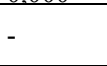 & $\begin{array}{l}0,441 * * \\
0,000\end{array}$ & $\begin{array}{l}0,412 * * \\
0,000\end{array}$ & $\begin{array}{l}0,321 \text { ** } \\
0,001\end{array}$ & $\begin{array}{l}0,048 \\
0,111\end{array}$ \\
\hline $\begin{array}{l}\text { Системи підтримки } \\
\text { прийняття рішень }\end{array}$ & & & & 0,000 & $\begin{array}{l}0,425 * * \\
0,000\end{array}$ & $\begin{array}{l}0,119 \\
0,082\end{array}$ & $\begin{array}{l}0,115 \\
0,321\end{array}$ \\
\hline $\begin{array}{l}\text { Стратегічний } \\
\text { управлінський облік }\end{array}$ & & & & & 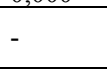 & $\begin{array}{l}0,625^{* *} \\
0,000 \\
\end{array}$ & $\begin{array}{l}0,328^{* *} \\
0,002 \\
\end{array}$ \\
\hline $\begin{array}{l}\text { Фінансова } \\
\text { ефективність }\end{array}$ & & & & & & 0,000 & $\begin{array}{l}0,285^{* *} \\
0,001\end{array}$ \\
\hline $\begin{array}{l}\text { Нефінансова } \\
\text { ефективність }\end{array}$ & & & & & & & - \\
\hline
\end{tabular}

Примітки: * - статистична значимість відповідно на: *** 1\%; **5\%; *10\%. Ажерело: авторське дослідження.

Таблиця 4. Практика управлінського обліку та ефективність

\begin{tabular}{|l|l|l|}
\hline \multicolumn{1}{|c|}{ Інструменти } & \multicolumn{1}{|c|}{$\begin{array}{c}\text { Фінансова } \\
\text { ефективність }\end{array}$} & $\begin{array}{c}\text { Нефінансова } \\
\text { ефективність }\end{array}$ \\
\hline Системи обліку витрат & 1201 & 1307 \\
& 0,021 & 0,041 \\
\hline Бюджетування & 1439 & 1867 \\
& 0,003 & 0,301 \\
\hline Оцінка ефективності & 1637 & 1845 \\
& 0,008 & 0,354 \\
\hline Системи підтримки & 2621 & 2647 \\
прийняття рішень & 0,891 & 0,362 \\
\hline Стратегічний & 2911 & 2823 \\
управлінський облік & 0,048 & 0,008 \\
\hline
\end{tabular}

Ажерело: авторське дослідження.

Компанії, які вже використовують методи управлінського обліку, виявляють великий інтерес до нових інструментів стратегічного управлінського обліку. Компанії, які тільки починають запроваджувати управлінський облік, виявляють зацікавленість більш традиційними інструментами управлінського обліку системи обліку витрат та бюджетування.

Аля аналізу впливу систем ПУО на результативність користувачів і компаній-некористувачів використано непараметричний підхід. У таблиці 3 наведено результати кореляційного аналізу.

Результати тесту коефіцієнту кореляції ранжування Спірмена показують позитивні та статистично значущі зв'язки між більшістю інструментів управлінського обліку та показниками готельного бізнесу. Зокрема, системи обліку витрат та стратегічний управлінський облік мають позитивне й значуще співвідношення стосовно показників фінансової та нефінансової діяльності. На відміну від цього, методи бюджетування та оцінки ефективності мають позитивний й значний вплив лише на рентабельність інвестицій. Системи підтримки прийняття рішень, не впливають на результати діяльності компанії.

3 метою аналізу відмінності між користувачами ПУО і некористувачами, у таблиці 4 зроблено U-критерій Манна-Уітні.

Результати підтверджують, що система обліку витрат впливає як на фінансові, так і на нефінансові результати готельних компаній.

Зокрема, система бюджетування та методи оцінки ефективності визначають фінансові результати компаній-користувачів, ніж некористувачів. Крім того, прихильники стратегічного управлінського обліку мають значно кращі фінансові та нефінансові результати, ніж інші фірми.

\section{ВИСНОВКИ}

Компанії індустрії гостинності були відібрані стратифікованим методом вибірки за економічним критерієм. Такий підхід дозволив отримати більш значущу вибірку. Загалом вибірка складається 330 компаній індустрії гостинності. Аля досягнення цілей дослідження було використано методологію кількісного аналізу для перевірки достовірності даних за допомогою анкети.

Аля аналізу впливу систем практики управлінського обліку на результативність компаній використано непараметричний підхід. Результати висвітлюють позитивні та статистичні значущі зв'язки між більшістю інструментів управлінського обліку та продуктивністю готельного бізнесу, що свідчить про те, що користувачі ПУО працюють краще, ніж некористувачі. Зокрема, система обліку витрат та стратегічний управлінський облік мають позитивне та значне співвідношення як щодо показника фінансової діяльності (ROI), так і щодо нефінансових показників. На відміну від цього, методи складання бюджету та оцінки ефективності мають лише позитивний і значний вплив на рентабельність інвестицій.

Крім того, користувачі ПУО мають значно кращі фінансові та нефінансові результати, ніж інші компанії. Нарешті, компанії, які вже використовують методи управлінського обліку, виявляють сильний інтерес до нових інстру- 
ментів стратегічного управлінського обліку, навіть якщо вони вважають методи бюджетування фундаментальними.

Результати дослідження можуть бути корисними для підвищення обізнаності підприємців щодо переваг (у контексті конкурентоспроможності та ефективності) від впровадження методів управлінського обліку.

\section{$\Lambda$ ітература:}

1. Костякова А.А. Управлінський облік як Ажерело інформаційного забезпечення системи управління. Молодий вчений. 2017. № 1. C. $49-54$.

2. Бруханський Р.Ф. Ідентифікація специфічних функцій стратегічного управлінського обліку. Інститут бухгалтерського обліку, контроль та аналіз в умовах глобалізації. 2020. № 1 . С. 7-18.

3. Аерій В.А., Гуменна-Аерій М.В. Управлінський облік і аналіз бізнес-процесів у підприємстві. Проблеми теорії та методології бухгалтерського обліку, контролю і аналізу. 2018. № 2 (40). C. 12-18.

4. Турова $\Lambda . \Lambda .$, Костюнік О.В. Проблеми впровадження управлінського обліку в Україні. Інвестиції: практика та досвід. 2018. № 5. C. $37-40$.

5. Афанас'єва I.І., Розмислов О.М. Сучасні тенденції трансформації уп равлінського обліку. Економіка і управління. 2020. № 8. С. 77-85.

6. Мазіна O.I. Значення глобальних принципів управлінського обліку у розвитку теорії, практики і професійних компетенцій. Економічний вісник. Серія: фінанси, облік, оподаткування. 2018. № 2. С. 83-90.

7. Azudin A., Mansor N. Management accounting practices of SMEs: The impact of organizational DNA, business potential and operational technology. Asia Pacific Management Review. 2018. Vol. 23. № 3. Pp. 222-226.

8. Amara T., Benelifa S. The impact of external and internal factors on the management accounting practices. International Journal of Finance and Accounting. 2017. Vol. 6. № 2. Pp. 46-58.

9. Adu-Gyamfi J., Chipwere K.Y.W. The Impact of Management Accounting Practices on the Performance of Manufacturing Firms: An Empirical Evidence from Ghana. Research Journal of Finance and Accounting. 2020. Vol. 11, № 20. Pp. 100-113.

10. Cuzdriorean D.D. The use of management accounting practices by Romanian small and medium-sized enterprises: A field study. Journal of Accounting and Management Information Systems. 2017. Vol. 16, № 2. Pp. 291-312.
11. Pham D.H., Dao T.H., Bui T. D. The Impact of Contingency Factors on Management Accounting Practices in Vietnam. The Journal of Asian Finance, Economics, and Business. 2020. Vol. 7, № 8. Pp. 77-85.

\section{References:}

1. Kostyakova, A. A. (2017), "Management accounting as a source of information of management system", Young scientist, vol. 1, pp. 49-54.

2. Brukhanskyi, R. F. (2020), "Identification of specific unctions of strategic management accounting", Institute of Accounting, Control and Analysis in the context of globalization, vol. 1, pp. 7-18.

3. Derii, V. A. and Humenna-Derii, M. V. (2018), "Management accounting and analysis of business processes in the enterprise", Problems of theory and methodology of accounting, control and analysis, vol. 2, no. 40, pp. 12-18.

4. Turova, L. and Kostiunik, O. (2018), "Problems of management accounting organization in the Ukrainian enterprises", Investments: practice and experience, vol. 5, pp. 37-40.

5. Afanasieva, I. and Rozmyslov, A. (2020), "Current trends of management accounting transformation", Economics and management, vol. 8, pp. 77-85.

6. Mazina, O. I. (2018), "The importance of global principles of management account in the development of theory, practice and professional competences", Economic Bulletin. Series: finance, accounting, taxation, vol. 2, pp. 83-90.

7. Azudin, A. and Mansor, N. (2018), "Management accounting practices of SMEs: The impact of organizational DNA, business potential and operational technology", Asia Pacific Management Review, vol. 23, no. 3, pp. 222-226.

8. Amara, T. and Benelifa, S. (2017), "The impact of external and internal factors on the management accounting practices", International Journal of Finance and Accounting, vol. 6, no. 2, pp. 46-58.

9. Adu-Gyamfi, J. and Chipwere, K. Y. W. (2020), "The Impact of Management Accounting Practices on the Performance of Manufacturing Firms: An Empirical Evidence from Ghana", Research Journal of Finance and Accounting, vol. 11, no. 20, pp. 100-113.

10. Cuzdriorean, D. D. (2017), "The use of management accounting practices by Romanian small and medium-sized enterprises: A field study", Journal of Accounting and Management Information Systems, vol. 16, no. 2, pp. 291-312.

11. Pham, D. H., Dao, T. H. and Bui, T. D. (2020), "The Impact of Contingency Factors on Management Accounting Practices in Vietnam", The Journal of Asian Finance, Economics, and Business, vol. 7, no. 8, pp. 77-85.

Стаття надійшла до редакиї 18.01.2022 p. 